\title{
Burrowing activity of Procambarus clarkii on levees: analysing behaviour and burrow structure
}

\author{
Phillip J. Haubrock (D) A Alberto F. Inghilesi • Giuseppe Mazza • \\ Michele Bendoni $\cdot$ Luca Solari $\cdot$ Elena Tricarico
}

Received: 16 February 2019/Accepted: 12 June 2019/Published online: 2 July 2019

(C) The Author(s) 2019

\begin{abstract}
The North American crayfish Procambarus clarkii is considered among the most invasive freshwater species. However, burrowing behaviour and the possible impact of $P$. clarkii on levees have not yet been studied in depth. To assess shape, volume and structure of its burrows and the associated behaviour, experiments were conducted introducing two sizematched adult crayfish into an artificial setup and video-recording their behaviour for $96 \mathrm{~h}$. At the end of each replicate, casts of excavated burrows made with polyethylene foam were retrieved. Crayfish $(n=40)$ dug 17 burrows, six of which having an enlarged terminal chamber. The average excavated levee volume of burrows was $1.9 \% \quad\left(0.00528 \mathrm{~m}^{3}\right.$; $5.02561) \pm 0.86 \%$ of the total volume with a maximum of $4 \%\left(0.0109 \mathrm{~m}^{3} ; 10.9 \mathrm{l}\right)$ and the chambers
\end{abstract}

P. J. Haubrock · A. F. Inghilesi

NEMO, Nature and Environment Management Operators s.r.l., 50121 Florence, Italy

P. J. Haubrock $(\square)$

Department of River Ecology and Conservation, Senckenberg Research Institute and Natural History Museum Frankfurt, 63571 Gelnhausen, Germany

e-mail: Phillip.Haubrock@Senckenberg.de

P. J. Haubrock

Faculty of Fisheries and Protection of Waters, South

Bohemian Research Center of Aquaculture and

Biodiversity of Hydrocenoses, University of South

Bohemia in České Budějovice, 38925 Vodňany,

Czech Republic (mean volume of $0.9 \pm 0.6 \mathrm{dm}^{3}$ ) contributed to up to $50 \%$ of the excavated volume. No significant difference between sexes was found for any observed behaviour. Our study also demonstrated how $P$. clarkii female and male behaviours are similar for burrowing activity. As a result, we quantify the potential pressure exerted by the red swamp crayfish on levees and lastly highlight the observation of cooperating burrowing behaviour of male and female individuals in this species.

Keywords Red swamp crayfish - Impact assessment · Invasive alien species - Impact 


\section{Introduction}

As an effect of the advancing breakdown of biogeographic barriers, the introduction of alien invasive species is ranked among the main drivers of biodiversity loss (Sala et al. 2000; Clavero and García-Berthou 2006; Millennium Ecosystem Assessment 2005; Copp et al. 2014a, b), and homogenization of ecosystems (Rahel 2002). Invasive alien species (IAS) have often caused irreversible damage (Jackson et al. 2002; Keller et al. 2011), eliciting severe ecological, economic and social impacts (Gherardi et al. 2009; Mazza et al. 2014a). The lack of geographical barriers (Lodge 1993), the specifically high intrinsic dispersal ability of aquatic organisms (Ricciardi and Rasmussen 1999; Beisel 2001) and extensive human influence make freshwater ecosystems particularly prone to biological invasions (Havel et al. 2015).

The North American crayfish Procambarus clarkii is considered a highly invasive species (Henttonen and Huner 1999; Huner 2002) that has been intentionally introduced (Holdich 1999, 2016) throughout the world in the twentieth century (Lodge et al. 2012). The European invasion by $P$. clarkii began with an introduction to Spain in 1973 for aquaculture purposes (Souty-Grosset et al. 2016). The species has steadily spread across Europe, becoming abundant in Portugal, Spain, France and Italy. It was originally introduced to increase crayfish harvests (Souty-Grosset et al. 2006), but it is currently traded also for ornamental purposes (Mazza et al. 2015). Procambarus clarkii is a successful coloniser in Europe (Souty-Grosset et al. 2016), quickly establishing in new and different environments. It is listed among the 100 worst invasive species in Europe (Pyšek et al. 2011), and among the species of unional concern under the new EU Regulation 1143/2014 regarding alien invasive species. Procambarus clarkii, widespread in freshwater and even brackish ecosystems (Scalici et al. 2010; Souty-Grosset et al. 2016), has been recently reported to also colonise cave ecosystems (Mazza et al. 2014b). It exhibits a wide range of impacts through predation, competition, bioaccumulation and increased eutrophication, and pathogen and disease transmission (Barbaresi and Gherardi 2000; Angeler et al. 2001).

The ability to exert heavy impacts, while being tolerant to diverse environmental conditions, makes the species able to completely transform habitats, thus giving $P$. clarkii the role of an ecosystem engineer (sensu Jones et al. 1997). The species is considered a tertiary to secondary burrower (Gherardi 2000; but see also Ilhéu et al. 2003), i.e. digging burrows to withstand environmental extremes periods (e.g. drought) and during reproductive periods (Gherardi and Barbaresi 2000; Gherardi 2006; Souty-Grosset et al. 2014). It can thus overcome unfavourable conditions in the invaded habitat (Souty-Grosset et al. 2016). Its burrowing activity is known to vary according to soil particle size, water cycle and structure of land as well as to damage agricultural and natural systems, causing channel bank erosion (Fig. 1), increase of water turbidity and fine sediments (Huner 1977; Anastácio and Marques 1997; Holdich 1999; Rodríguez et al. 2003; Correia and Ferreira 1995), significant physical modification (Barbaresi et al. 2004; Orlandini et al. 2015), and reduction of plant density (Souty-Grosset et al. 2014). Moreover, burrowing animal species have been identified as one of the main causes for levee failures (Chang and Lange 1967; Rudnick et al. 2000; Gribsholt et al. 2003; Serre et al. 2008; Hanson et al. 2010) causing floods (Fig. 1) and damage in excess of $\$ 500$ million in Italy (Orlandini et al. 2015). In Italy, crayfish burrowing activity has already damaged about $30 \%$ of partially human shaped irrigation canals with huge costs for management authorities (F. Gherardi in Lodge et al. 2012).

Previous studies have investigated the burrowing behaviour of invasive crayfish outside their native range (Correia and Ferreira 1995; Kouba et al. 2016), but only a very few have directly quantified burrow morphology and related this directly to damage of river banks and/or levees (e.g. Guan 2010; Consumi 2016).

Behaviour of crayfish in invaded habitats can differ from that in the native range. For example, the signal Crayfish ( $P$. leniusculus) is considered to be a nonburrowing species in its native North American range but commonly burrows in riverbanks of invaded habitat in England (Guan 2010). Mating between male and female $P$. clarkii usually occurs before females start to burrow (Huner and Barr 1991). Females hold eggs and rear juveniles in the burrow but the extent of male participation in the construction and defence of the burrow remains unexplored. Hence, the aim of the present work is to assess the burrowing activity of $P$. clarkii, analyse the structure of the constructed burrows and the behaviour displayed by 

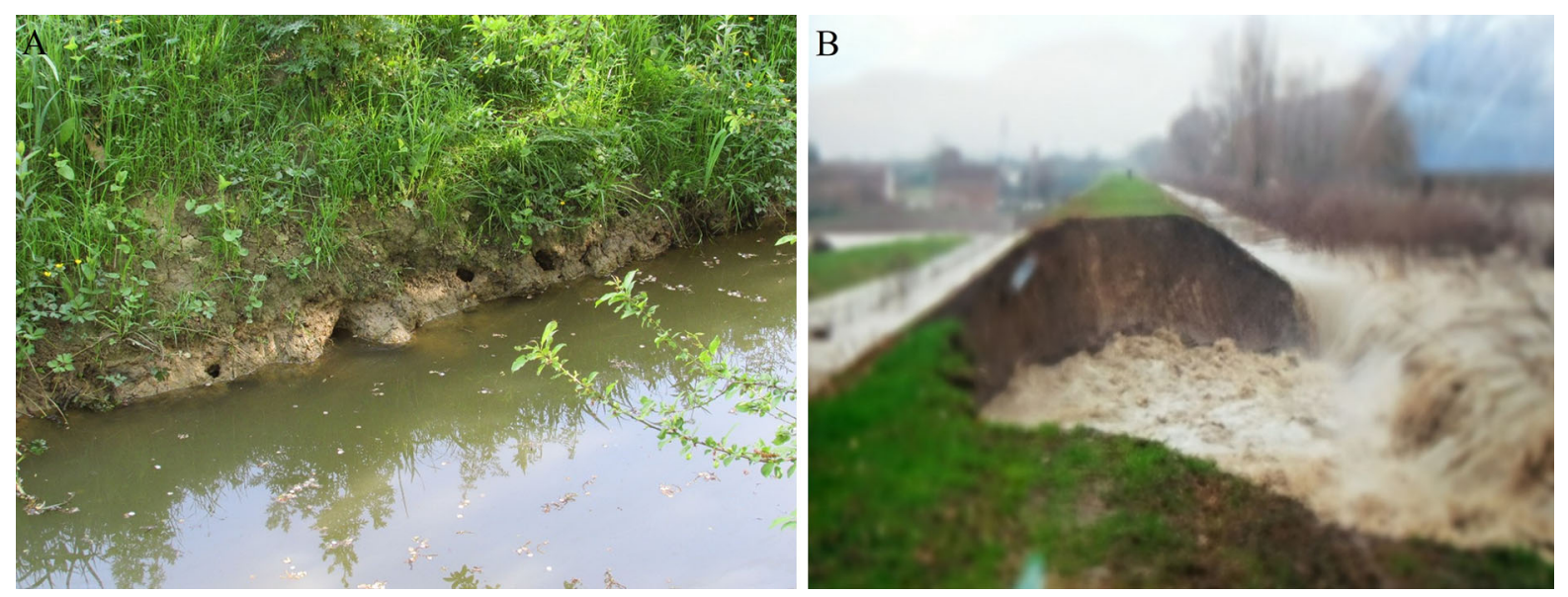

Fig. 1 a Typical burrows produced by Procambarus clarkii on irrigation ditches; b due to the burrowing activity of Procambarus clarkii broken levee alongside the river Secchia (Emilia Romana, Italy)

male and female crayfish to identify possible differences between sexes.

\section{Methods}

\section{Structure of burrows}

In spring 2016, 80 specimens of $P$. clarkii were collected in local ponds in northern Tuscany (Central Italy) using baited traps. Cephalothorax lengths (CL) were measured using a Vernier calliper (accuracy: $0.01 \mathrm{~mm}$ ) and then labelled (numbers and letters) on the cephalothorax using a white marker. The specimens were maintained in plastic containers $(12.5 \times 22.5 \times 13 \mathrm{~cm}$; water level: $3 \mathrm{~cm}$; weekly water change) for the entire duration of this study in the laboratory of the Department of Biology, University of Florence, under a natural light/dark cycle at room temperature (range $17.1-25.7{ }^{\circ} \mathrm{C}$ ) and fed with carrots. Carrots are commonly used to feed $P$. clarkii under laboratory conditions as they are considered as an ideal food source due to the diet spectrum of mature $P$. clarkii and carotenoids sustaining its natural red colouration (Huner and Meyers 1979; Gherardi et al. 2013). Three days before the start of each experiment, specimens were moved in the same plastic containers to DICEA (Department of Civil and Environmental Engineering, University of Florence) laboratory. Mature adult specimens with cephalothorax length comprised between 36 and $46 \mathrm{~mm}$ (average length: $44.5 \pm 3.1 \mathrm{~mm}$ ) were selected, being the individuals of this size the most active (in terms of mobility) and frequent in natural environments (Gherardi et al. 2000). For each replicate, two couples were formed, composed of size-matched (maximum difference CL: 5-6\%) male and female, and, after each replicate, were not used for further experiments. To minimize bias in the experiments, only individuals in good condition without mutilations were selected. From April to August 2016, ten independent replicates of the experiment were conducted, each in five-day cycle using artificial model levees simulating Italian irrigation canals built at laboratory of DICEA. The experimental soil granulometry (composed of $61 \%$ silt, $21.7 \%$ sand, $17 \%$ clay and $0.3 \%$ gravel) is particularly favourable to crayfish burrowing activity (Barbaresi et al. 2004) and is typically used by local Basin Authorities for the construction of levees in many areas colonized by this species in Tuscany. The scale of the constructed levee was a 1:1 copy (same size as levees in the field) of levees that can be frequently found along ditches (Fig. 1), the most commonly invaded habitat by $P$. clarkii.

The levee was constructed in a static water tank (L: $300 \mathrm{~cm}$; W: $96 \mathrm{~cm}$; H: $110 \mathrm{~cm}$ ) during 3 days prior to the 5-day cycle of each experimental replicate. It was built by laying multiple soil layers (5-8) of approximately $10-12 \mathrm{~cm}$ height on top of each other with the first one being rectangular shaped $(100 \times 96 \times 10 \mathrm{~cm})$ and each consecutives layer decreasing in size. All layers, except the bottom one, were compacted using a common dynamic loading procedure whereby soil was regularly hit by a given 


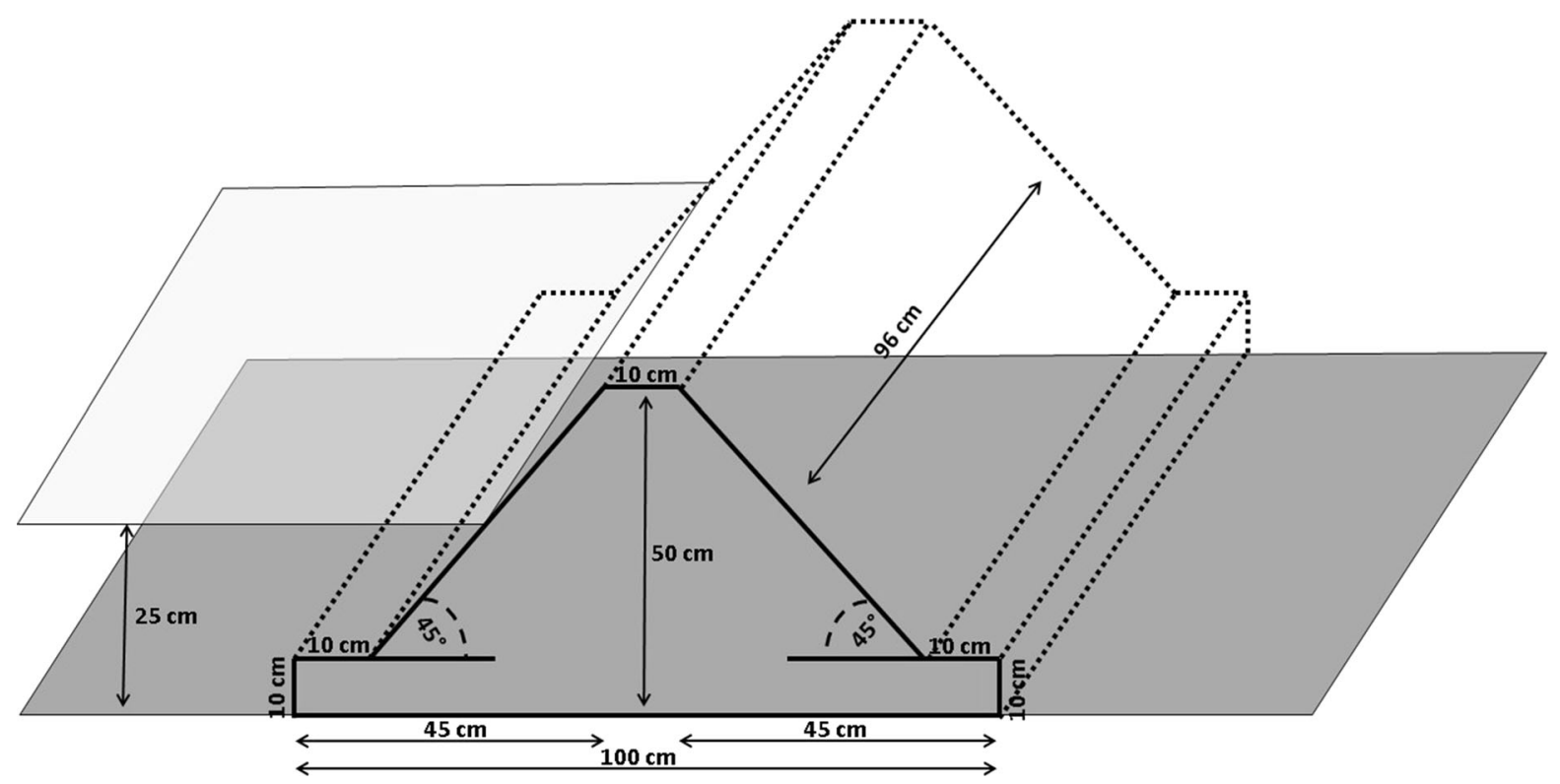

Fig. 2 Model of the artificial levee used for the experiment at DICEA (Department of Civil and Environmental Engineering, University of Florence)

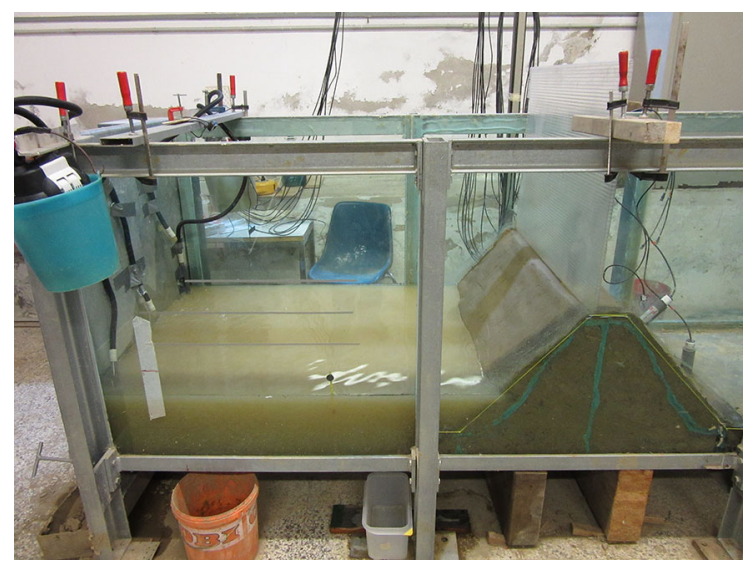

Fig. 3 Constructed model levee at DICEA (Department of Civil and Environmental Engineering, University of Florence) $48 \mathrm{~h}$ after release of crayfish into the setup

weight of about $15 \mathrm{~kg}$ from a height of about $20 \mathrm{~cm}$. The first day and before laying soil layers, portions of hydro-expanding bentonite (waterstop) were attached to the glass sides and middle section of the tank bottom to prevent preferential water pathways along the contact surfaces. The completed levees had a trapezoidal shape over a wider rectangular basal layer, total height was $50 \mathrm{~cm}$ and length $100 \mathrm{~cm}$ (Figs. 2, 3).

Before each replicate, water level (at room temperature) was set to $25 \mathrm{~cm}$ on one side to cover $50 \%$ of the levees height and maintained constant during the experiment; this level gave the possibility to observe the burrowing behaviour of crayfish in the levee. A barrier was put on top of the levee to exclude movements of crayfish from the waterside to the empty side. On the first day of each replicate (after the 3 days to build the model), two pairs of size-matched crayfish were placed into the water and the experiment was video-recorded for 96 consecutive hours. During night-time, light was provided by a halogen lamp covered with a blue filter simulating "moon light", enabling observing animal movements without disturbance. Air and water temperature were recorded during all the experimental replicates and controlled as best as possible but were subject to fluctuations due to the different climatic conditions occurring during the study period. At the end of the replicate, crayfish were baited out of the burrows using cat food. Then, water was removed from the tank and from the burrows, using a syringe and a rubber pipe if needed. Polyethylene foam was inserted into the burrows while applying pressure on the entrance to ensure that the foam could expand inside the burrow. To be sure that every burrow was filled with foam, the levee was taken down carefully, injecting more foam in instances when empty burrows were uncovered. After the entire structure was taken down, the foam structure was 


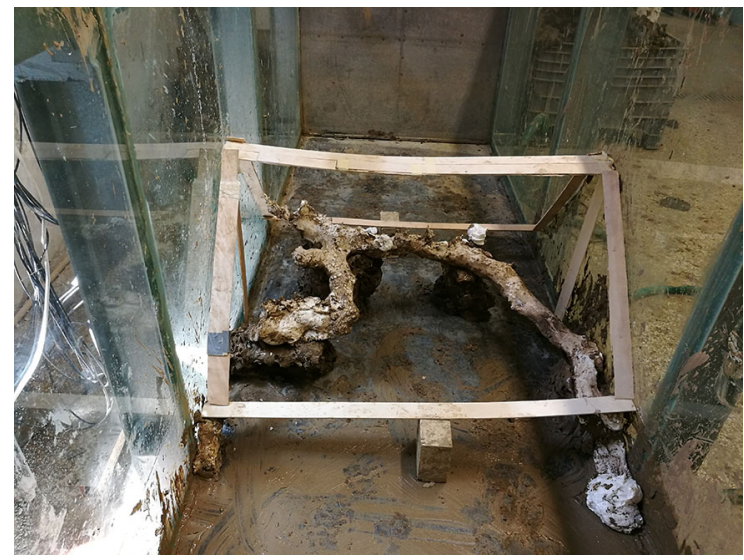

Fig. 4 Reconstructed model of the levee after the experiment, showing the position of burrows and the excavated volume of burrows

placed in the empty and cleaned tank to take pictures (Fig. 4). The total excavated volume was measured by submerging the foam structure in a volumetric water bowl. The maximum length (longest tunnel) of each burrow, the maximum and minimum diameter of each tunnel at its beginning, middle and end section were also measured to generate a single mean diameter value per tunnel. The presence, diameter and volume of each chamber (enlarged structure which significantly differs from the tunnel; Gherardi 2000) as well as the presence of multiple openings were assessed.

\section{Behavioural parameters}

The following parameters were recorded from the camera placed in a $90^{\circ}$ angle over the levee-front and analysed for each individual: (1) latency in seconds (time until crayfish started burrowing after being placed into the setup); (2) time in seconds spent in different behaviours, such as "burrowing" (i.e. visible active digging into the soil on the external surface of the levee), "burrow protection" (i.e. standing directly in or above the burrow edge), "horizontal movement" (i.e. movement under the water level on top of the first rectangular layer of the levee), "outside movement" (i.e. movement outside of the water line), and "breathing" (i.e. the typical sideway position used in this species to breath air oxygen outside the water, see Holdich 1999). When animals were in the burrow, no activity could be recorded.
Statistical analyses

Data were tested for normality by applying the Shapiro-Wilk's test ( $p>0.05)$, skewness and kurtosis z-values $(-1.96$ to +1.96$)$ and displaying the data distribution using histograms, normal Q-Q plots and boxplots. Data on burrowing latency did not meet assumption of normality and were analysed in relation to sexes, using a Mann-Whitney-U test. Burrow latency, burrow length, excavated volume and air temperature were analysed with Spearman correlations. To test whether one sex started new burrows significantly more often than the other, Chi square $\left(\chi^{2}\right)$ test was applied. Following the statistical approach by Gherardi et al. (2011), a two-way repeated measures multivariate analysis of variance (MANOVA; statistic: Wilk's Lambda $\Lambda$ ) was applied to all the behavioural parameters using sex and day/night as factors after assumptions of multivariate normality were controlled with quantile-quantile $(\mathrm{Q}-\mathrm{Q})$ plot and met. MANOVA was followed by univariate tests for between-subject's effects.

Using the data from all the experiments, time spent in each behavioural pattern was compared between day and night (Wilcoxon-signed-rank-test, statistic: W), and between sexes (Mann-Whitney-U-test, statistic: U). Moreover, behaviours of males and females were analysed separately between day and night (Wilcoxon-signed-rank-test, statistic: W). For replicate \#5 no video data were obtained due to a technical error in the camera setup. The level of significance under which the null hypothesis was rejected is $\alpha=0.05$. Text and figures give mean values \pm standard errors (SE) or median values $\left(+1^{\circ}\right.$ and $3^{\circ}$ interquartile). SPSS $®$, Statistical Package for Social Science 13.0 for Windows was used for the statistical analyses.

\section{Results}

Structure of burrows

Overall, 17 burrows were constructed by 40 crayfish during the ten experiments. In seven replicates, levees contained two burrows with three openings $(n=4)$ and two openings $(n=3)$. In the remaining three replicates, levees had only one burrow with two openings and in two cases burrows with only one 
Table 1 List of total numbers of burrows and entries constructed by crayfish during ten replicates plus information of occupation of burrows by crayfish at the end of each replicate

\begin{tabular}{llllll}
\hline Replicate & \# Burrows & \# Entries & Chamber present & \# Crayfish per burrows & \# Entries per burrow \\
\hline 1 & 1 & 2 & & 1 & 1 \\
2 & 2 & 2 & & $2 / 2$ & 1 \\
3 & 2 & 3 & $\mathrm{x}$ & $2 / 1$ & $1 / 2$ \\
4 & 2 & 3 & $\mathrm{x}$ & $2 / 2$ & $1 / 2$ \\
5 & 1 & 1 & & 2 & 1 \\
6 & 1 & 1 & & 1 & $1 / 2$ \\
7 & 2 & 3 & $\mathrm{x}$ & $2 / 0$ & $1 / 2$ \\
8 & 2 & 3 & $\mathrm{x}$ & $2 / 2$ & 1 \\
9 & 2 & 2 & $\mathrm{x}$ & $2 / 1$ & 1 \\
10 & 2 & 2 & $\mathrm{x}$ & $1 / 1$ & \\
\hline
\end{tabular}

In case of two numbers (e.g. 2/2) within a column, the numbers refer to the number of burrows

opening (Table 1). During ten replicates and out of 17 burrows, only five replicates contained chambers $(n=6)$ which were constructed directly at the end of the entry tunnels with two having partially constructed tunnels outgoing from it (Fig. 4).

Mean size of chambers $(n=6)$ was $15.8 \pm 5.2$ (height) $\times 11.4 \pm 2.5$ (width) $\times 10.9 \pm 1.3$ (depth) $\mathrm{cm}$ and had a mean volume of $0.9 \pm 0.6 \mathrm{dm}^{3}$. The average length of the excavated tunnels was $50.2 \pm 32.4 \mathrm{~cm}$ (ranging from 7.0 to $123.6 \mathrm{~cm}$ ) with a mean perimeter of tunnel sections of $17.9 \pm 2.4 \mathrm{~cm}$ (ranging from 14.1 to $21.6 \mathrm{~cm}$ ). Diameter of tunnels ( $\mathrm{n}=17$ ) was shown to be between $4.8 \pm 0.9 \mathrm{~cm}$ and $6.0 \pm 1.0 \mathrm{~cm}$. The excavated volume on the total levee volume showed a mean of $1.9 \% \pm 0.9 \%$ $\left(0.00528 \mathrm{~m}^{3} ; \quad 5.0256 \mathrm{l}\right)$ with $1.0 \% \quad\left(0.0024 \mathrm{~m}^{3}\right.$; $0.24 \mathrm{l})$ being the smallest and $4.0 \%\left(0.011 \mathrm{~m}^{3}\right.$; 10.9 l) the largest percentage of excavation. In seven replicates, crayfish were found to occupy burrows in couples of one female and one male (Table 1). Additionally, in various replicates one pair of crayfish constructed a complex burrow while the other pair constructed a shorter and simpler structure (Tables 1, 2).

\section{Behavioural parameters}

In seven cases, the establishment of couples (i.e. both sexes starting burrowing together without fighting and protecting the burrow against other individuals) was observed after $5100 \pm 1452$ s. No correlation was found between latency time and burrow length ( $\mathrm{rs}=$ $0.25, \mathrm{n}=7, \mathrm{p}=0.589$ ), latency time and excavated volume ( $r s=0.452, n=7, p=0.260)$, burrow length and excavated volume $(\mathrm{rs}=-0.43, \mathrm{n}=7$, $\mathrm{p}=0.337$ ), air temperature and latency time ( $\mathrm{rs}=$ $-0.71, \mathrm{n}=7, \mathrm{p}=0.071$ ), temperature and burrow length ( $\mathrm{rs}=0.19, \mathrm{n}=7, \mathrm{p}=0.602)$. Overall, males and females started constructing burrows with the same frequency $\left(\chi^{2}=1.17 ; \mathrm{n}=13 ; \mathrm{p}=0.279\right.$; females: $\mathrm{n}=8$; males: $\mathrm{n}=5$ ), also in case of the first burrow ( $\mathrm{n}=4$ for both sexes). Both sexes did not significantly differ for latency time $(\mathrm{U}=15, \mathrm{n}=8$, $\mathrm{p}=0.06$; male: $740 \mathrm{~s}, 486-1862 \mathrm{~s}$; female: $3281 \mathrm{~s}$,

Table 2 Description of excavated structures (chambers and tunnels) during the experiments performed

\begin{tabular}{|c|c|c|c|c|c|c|c|}
\hline Structure & $\mathrm{n}$ & $\begin{array}{l}\text { Mean length } \\
(\mathrm{cm})\end{array}$ & $\begin{array}{l}\text { Mean perimeter } \\
(\mathrm{cm})\end{array}$ & $\begin{array}{l}\text { Mean height } \\
(\mathrm{cm})\end{array}$ & $\begin{array}{l}\text { Mean width } \\
(\mathrm{cm})\end{array}$ & $\begin{array}{l}\text { Mean depth } \\
(\mathrm{cm})\end{array}$ & $\begin{array}{l}\text { Mean volume } \\
\left(\mathrm{m}^{3}\right)\end{array}$ \\
\hline Chamber & 6 & & & $15.8 \pm 5.2$ & $11.4 \pm 2.5$ & $10.9 \pm 1.3$ & $0.00098 \pm 0.0006$ \\
\hline Tunnel & 17 & $50.2 \pm 32.4$ & $17.9 \pm 2.4$ & & & & $0.0043 \pm 0.0016$ \\
\hline Total & & & & & & & $0.00528 \pm 0.0023$ \\
\hline
\end{tabular}


Fig. 5 Total time spent in each behaviour (\%) through the nine replicates. Left y-axis: \% of each behaviour, right y-axis: maximum air temperature measured during each experiment

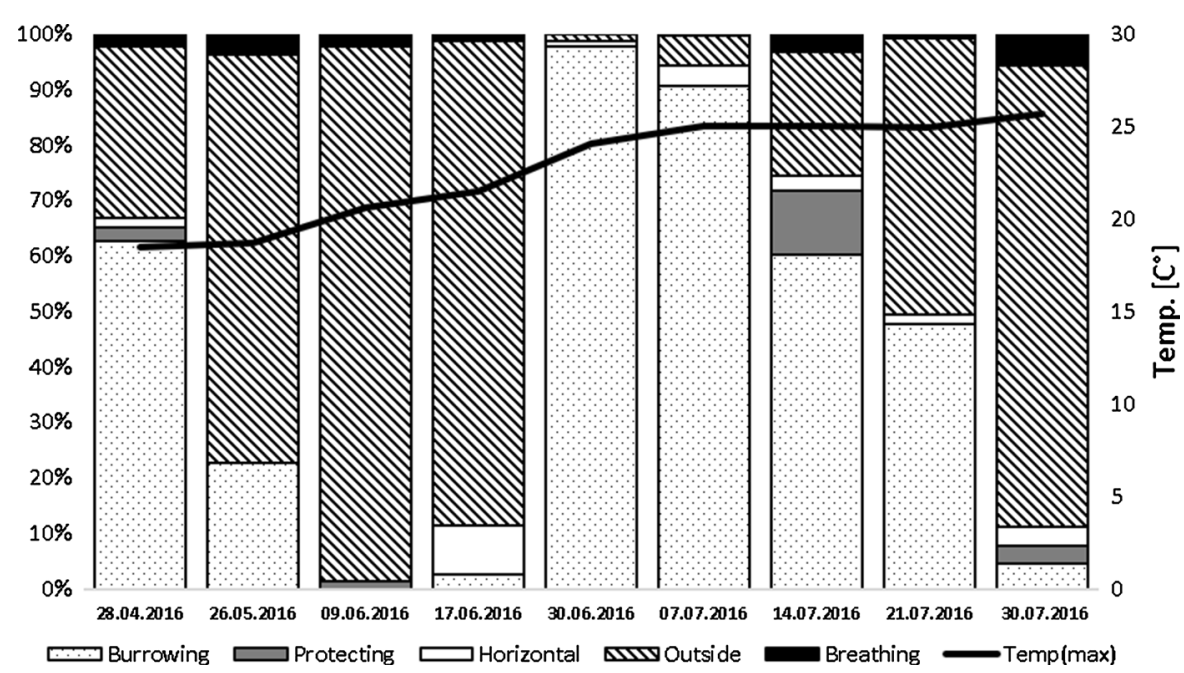

(Orlandini et al. 2015; Condicelli 2016) is described, and the behaviour of Procambarus clarkii associated with the construction of burrows in an artificially environment is analysed (but see also Kouba et al. 2016). The results showed that crayfish promptly started digging and that both sexes are involved in burrowing activity. These data are thus important to increase the knowledge of $P$. clarkii biology and could help develop levee structures that are less vulnerable to the presence of $P$. clarkii under consideration of burrow structure (Kouba et al. 2016).

\section{Structure of burrows}

In the present study, two types of burrows were observed: (1) complex burrow with entrances at the water line commencing straight into the levee (Fig. 6a, c) and in some cases with a central chamber, which volume can contribute to almost $50 \%$ to the overall excavation volume of the burrows, and (2) a considerable number of short burrows constructed u-shaped and placed near the ground in the first basal layer of the levee (Fig. 6b), as described by Holdich and Lowery (1988). While some variation between experimental and natural conditions are possible, obtaining similar data from the field is very difficult due to inaccessibility of levees. However, due to the simulation of similar conditions (no vegetation, presence of water, 50-50 sex ration, comparable densities), results presented in this study are likely to be expected under natural conditions. However, the overall low level of 
Table 3 Comparisons between sex and day time, within sex and within day time for each behavioural parameter, using MannWhitney-U test [U] or Wilcoxon-signed-rank test [W]
Medians and $1^{\circ}-3^{\circ}$ interquartile are reported. Significant values are highlighted in bold

\begin{tabular}{|c|c|c|c|c|}
\hline Factor & Behaviour & $\mathrm{n}$ & $\mathrm{p}$ & Time (s) \\
\hline \multicolumn{5}{|l|}{ Males vs. females } \\
\hline \multirow[t]{5}{*}{ Day and night } & Burrowing & 36 & 0.743 & $0(0-3464)$ \\
\hline & Protection & 36 & 0.767 & $0(0-621)$ \\
\hline & Horizontal & 36 & 0.372 & $39(0-227)$ \\
\hline & Outside & 36 & 0.563 & $2199(420-10052)$ \\
\hline & Breathing & 36 & 0.203 & $55(0-441)$ \\
\hline \multirow[t]{5}{*}{ Day } & Burrowing & 18 & 1.000 & $3383(243-11033)$ \\
\hline & Protection & 18 & 0.796 & $0(0-755)$ \\
\hline & Horizontal & 18 & 0.546 & $100(0-481)$ \\
\hline & Outside & 18 & 0.863 & $3515(1028-15961)$ \\
\hline & Breathing & 18 & 0.436 & $150(0-688)$ \\
\hline \multirow[t]{5}{*}{ Night } & Burrowing & 18 & 0.730 & $0(0-0)$ \\
\hline & Protection & 18 & 0.931 & $0(0-147)$ \\
\hline & Horizontal & 18 & 0.605 & $0(0-113)$ \\
\hline & Outside & 18 & 0.546 & $1604(36-5336)$ \\
\hline & Breathing & 18 & 0.297 & $45(0-332)$ \\
\hline \multicolumn{5}{|l|}{ Day vs. night } \\
\hline \multirow[t]{10}{*}{ Males and females } & Burrowing & 18 & 0.001 & Day: 3383 (243-11033) \\
\hline & & & & Night: $0(0-0)$ \\
\hline & Protection & 18 & 0.018 & Day: 0 (0-755) \\
\hline & & & & Night: $0(0-147)$ \\
\hline & Horizontal & 18 & 0.004 & Day: $100(0-481)$ \\
\hline & & & & Night: $0(0-113)$ \\
\hline & Outside & 18 & 0.124 & Day: 3515 (1028- 15962) \\
\hline & & & & Night: 1604 (36-5336) \\
\hline & Breathing & 18 & 0.334 & Day: 150 (0-688) \\
\hline & & & & Night: 45 (0-332) \\
\hline \multirow[t]{10}{*}{ Males } & Burrowing & 9 & 0.012 & Day: 3222 (228-21674) \\
\hline & & & & Night: $0(0-0)$ \\
\hline & Protection & 9 & 0.068 & Day: 0 (0-758) \\
\hline & & & & Night: $0(0-338)$ \\
\hline & Horizontal & 9 & 0.043 & Day: $18(0-550)$ \\
\hline & & & & Night: $0(0-112)$ \\
\hline & Outside & 9 & 0.327 & Day: 4205 (1575-11455) \\
\hline & & & & Night: 2296 (24-7259) \\
\hline & Breathing & 9 & 0.499 & Day: 55 (0-558) \\
\hline & & & & Night: $12(0-172)$ \\
\hline \multirow[t]{10}{*}{ Females } & Burrowing & 9 & 0.018 & Day: 6009 (416-14519) \\
\hline & & & & Night: $0(0-0)$ \\
\hline & Protection & 9 & 0.109 & Day: 0 (0-974) \\
\hline & & & & Night: 0 (0-294) \\
\hline & Horizontal & 9 & 0.028 & Day: 108 (31-490) \\
\hline & & & & Night: $0(0-169)$ \\
\hline & Outside & 9 & 0.214 & Day: 2825 (473-16731) \\
\hline & & & & Night: 642 (198-8720) \\
\hline & Breathing & 9 & 0.484 & Day: 244 (22-764) \\
\hline & & & & Night: 268 (19-438) \\
\hline
\end{tabular}



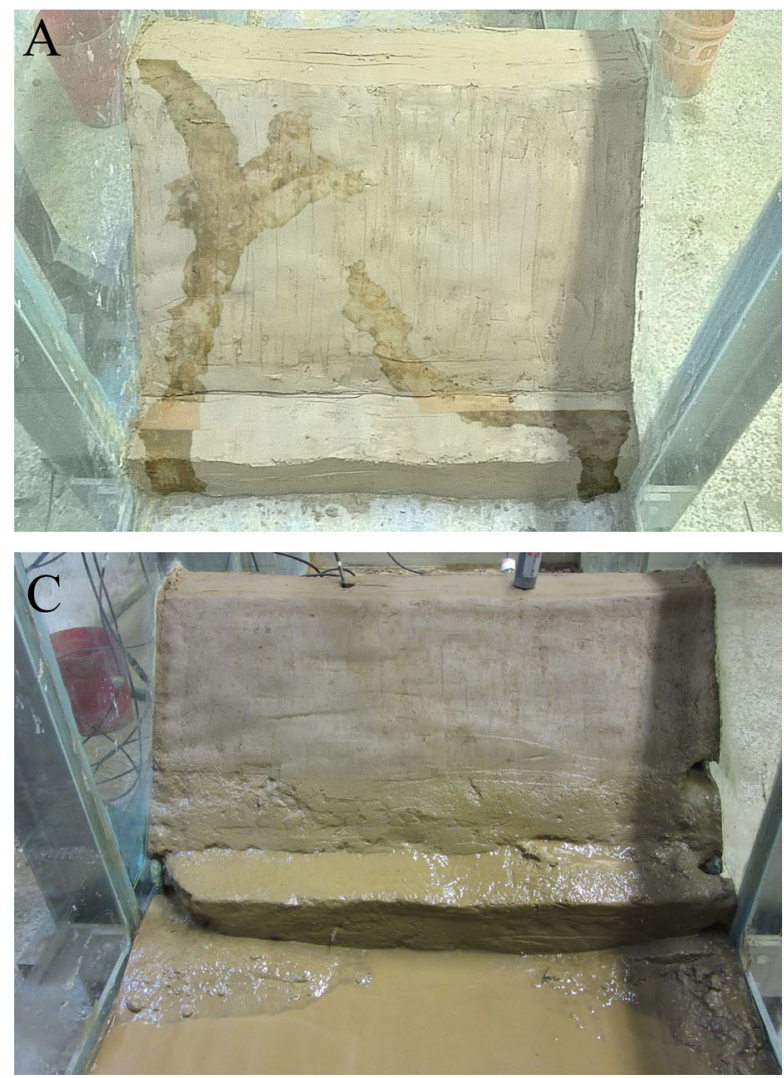

Fig. 6 Reconstructed model of the levee after the experiment, showing the position and the excavated volume of burrows. a, b Observed burrows as positioned inside the levee; c frontal view of the model levee after water has been removed showing both types of typically constructed burrows: the straight into the

variation (only two types of burrows) was likely due to the constant water level (Holdich and Lowery 1988; Ilhéu et al. 2003) and the experimental setup, but is in agreement with previous studies that also reported complex and simple burrow structures (Correia and Ferreira 1995; Ilhéu and Bernardo 1996; Gherardi et al. 2002) with similar burrow opening diameters (Souty-Grosset et al. 2014), with a burrow depth ranging from 0.28 to $0.58 \mathrm{~m}$ (Portugal: Correia and Ferreira 1995).

In contrast to the horizontally burrows constructed at $0-20 \mathrm{~cm}$ below the water level, previously described burrows showed a simpler morphology, with usually one opening at a distance of $0-10 \mathrm{~cm}$ above the water surface enlarging in a tunnel with a terminal chamber, potentially with muddy plugs or a chimney reaching up over the burrow opening. These were generally occupied by two mature crayfish

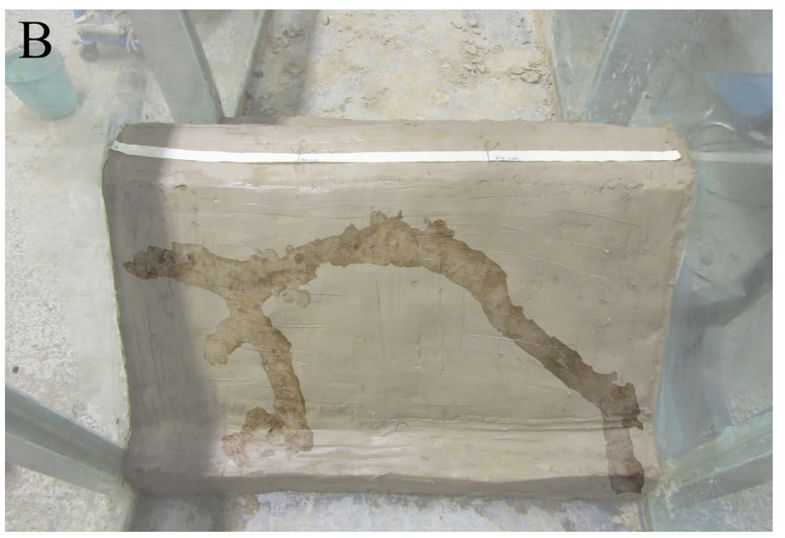

$\mathrm{D}$

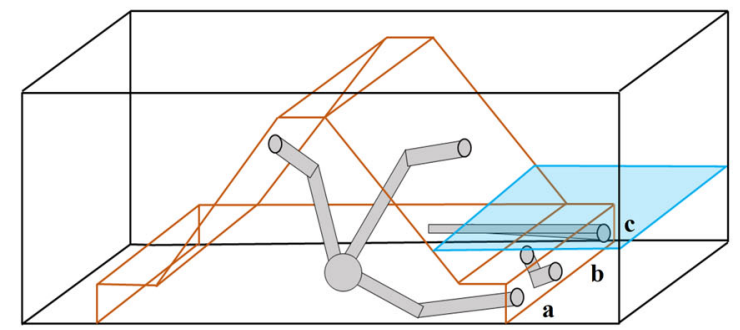

levee dug burrows near the water line and the "u-shaped" burrows near the ground.; $\mathbf{d}$ model of all differing types of burrow structures observed during the experiments, a: complex structure with chamber, b: "u-shaped" burrow, c: blind tunnel commencing straight in the levee

(Jaspers and Avault 1969; Correia and Ferreira 1995) as observed in ten out of 17 constructed burrows in the present study. From field observations conducted in July 2017, three out of seven burrows had a chamber (P. Haubrock, pers. comm.). In Europe, burrows can be inhabited by about 4.8 younger individuals, on average (Correia and Ferreira 1995), while in the native area by up to 50 individuals (Huner et al. 1984). We found that the ultrastructure of constructed chambers was overall consistent with previous described structures (Jaspers 1969; Huner and Barr 1984; Correia and Ferreira 1995; Ilhéu and Bernardo 1996). On the contrary, Souty-Grosset et al. (2014) observed more complex burrowing activity in dry fishponds, with burrows having also mud plugs. Besides water level, morphology, slope and structure of levee could have influenced the type of burrows constructed in the present study. 
Generally considered as a "secondary burrower" in its native area, this species spends most of its life outside of burrows, retreating into them for reproduction, and to avoid predation or dehydration. However, this species often seems to be considered as a "secondary to tertiary burrower" (depending on whether the author considers burrow usage or burrow structure; Hobbs and Hart 1959; Holdich 1999) in invaded area, due to its ability to shift its behaviour according to the different environments (Souty-Grosset et al. 2014). Hence, it is likely that burrowing behaviour, burrow structure and use of burrows differ among invaded areas due to differing particle size and water cycle (Souty-Grosset et al. 2014) as well as location of burrow (ground vs. levee, Condicelli 2016; Solari et al. 2016).

Although the experimental setup was not suited to analyse the different burrow types under dry conditions (vertical and submerged burrows-see Gherardi et al. 2002), two different types of burrows were produced. As stated by Barbaresi et al. (2004) and Correia and Ferreira (1995), apart from the presence of rocks that seemingly decrease the burrowing activity (Souty-Grosset et al. 2014), sediment composition, presence of vegetation and water availability affect the structure of constructed burrows.

This becomes obvious, as (i) shelter (i.e. rocks, structure) would provide additional cover and reduce burrowing activity, (ii) too small or large particles would increase the difficulty of burrow-construction (Barbaresi et al. 2004; Solari et al. 2016), and (iii) vegetation (and the roots within the sediment) affect the porosity of the sediment (Ilhéu et al. 2003; SoutyGrosset et al. 2014). Additionally, Kouba et al. (2016) showed that $P$. clarkii is capable of constructing different burrow structures in response to environmental changes, directly increasing its survivability. In the present study, burrow structures were generally either "u-shaped" (Gherardi 2000) or, likely due to the availability of constant water levels, similar to secondary burrower burrow morphologies but horizontally with more complexity (Fig. 6), usually expected from "primary burrowers" (Hasiotis and Mitchell 1993; Holdich 2002; Gherardi et al. 2002). While the typical "u-shaped" burrow could be "tertiary", providing suitable for short time protection under low construction effort, the more complex "secondary burrow" morphologies may be advantageous (aeration, additional exit) and suitable for longer refuge. Nonetheless, considering the present experimental setup and the reproductive phase of this species in Italy overlapping with the time of the study, it is not clear why in various experiments only one pair of crayfish constructed a larger, more extensive burrow, while the other pair remained constructing the previously mentioned u-shaped burrow. While a lack of space is possible, interactions between couples as well as different responses to the experimental setup (directly constructing a more permanent shelter vs. trying to get shelter fast) are probable.

The recorded burrowing activity led to a total amount of excavation up to $4 \%$ of the levee volume (with a high percentage of the excavated volume contributed by the chambers), that can directly affect levee stability and alter the seepage process by shortening filtration pathways with consequent possible collapse of the levee (Consumi 2016; Solari et al. 2016). Since the constructed model levee was a reproduction of typically irrigation canal levees, a damage and threat to the stability of levees similar to that ones we observed in the laboratory can be hypothesized for levees in nature, considering that the number of burrows increases over time (Barbaresi et al. 2004).

In order to avoid cannibalism and aggressive interactions, the density used in the experiment was low (four crayfish per $\mathrm{m}^{2}$ ). Moreover, according to the Catch Per Unit Effort values found in field studies (e.g. $>$ 20: Aquiloni et al. 2010; Cecchinelli et al. 2012) or densities used in semi-natural studies to quantify species impact $\left(8 \mathrm{~m}^{-2}\right.$ : Gherardi and Acquistapace 2007), higher abundances of $P$. clarkii are possible. However, the general layout (shape and granulometry) simulated model levees in Italy, as they are usually not covered in vegetation and free of structure, offer low to no shelter in surface waters (Figs. 4, 6), reproducing the burrowing activity observed in invaded habitats. Because burrow density is stated to be independent from crayfish density (Barbaresi et al. 2004; Tricarico et al. 2010), $4 \%$ of excavation by four individuals seems low, but the estimated percentage relates to $96 \mathrm{~h}$. With increasing time and potentially higher densities of $P$. clarkii, the probability of levee breaches as well as collapses increases (Condicelli 2016). Also, collapsing river banks are only one issue, while the creation of holes through irrigation ditches and related damage of the construction can lead to water leakage and shortage of water in irrigation 
canals for agriculture (Orlandini et al. 2015). Therefore, the excavation of $4 \%$ during $96 \mathrm{~h}$ can be considered as a high impact.

However, an intense immediately starting burrowing activity was always recorded in all the experiments, highlighting the considerable impact especially since $P$. clarkii tends to rebuild rather than reuse older burrows. Periodically changing of water level, due to the use of local waterways for irrigation and associated water cycle during summers, leads to a consistent annual fluctuation (water present between late autumn and spring, dried conditions during summer) and might induce an increased digging activity with a high impact on levee stability in times of drought, especially due to the presence of chambers as observed in this study, but ad hoc experiments are necessary to solve this issue. On the contrary, the constant shallow water level used in the experiments likely results in several shorter and horizontally constructed burrows (Gherardi et al. 2002) that will have a delayed effect on levees.

\section{Behavioural parameters}

Burrows were generally occupied by a couple composed by a male and a female as previously observed by Holdich and Lowery (1988). In the absence of shelter, both males and females began burrowing rapidly. Both sexes started digging, with similar latency time, and thus males did not initiate burrowing to induce mating. The observed data however, enable speculation of a trend towards a decrease in latency time under an increase in temperature, highlighting the more active pattern and the possible relation to the reproductive phase (Daniels et al. 1994). Indeed, in Tuscany species reproduction usually occurs between June and July when females need a burrow (Gherardi et al. 2002). In this study, mating was not observed outside the burrow, but rather a protective guarding of females by males that immediately approached advancing other P. clarkii while both were constructing the entry of the respective burrow (P. Haubrock, pers. obs.). The rapid pairing of $P$. clarkii in malefemale couples and subsequent cooperative burrowing suggests several interesting hypotheses. For instance, it could be to induce mating but $P$. clarkii typically mates in open water before burrowing, and if it was to induce mating males would have initiated burrowing, but this was not the case. Since mating was never actually observed, it could just be that crayfish cooperated with burrowing to get underground (into shelter) more quickly as hypothesised for Cambarus hartii (Helms et al. 2013a). However, P. clarkii always collaborated in teams of one female and one male, leading to support that it was related to mating.

Additionally, both sexes displayed burrow protection, e.g. guarding outside the burrow entrance from other crayfish, and sharing the burrowing itself, indicating that before the mating, both contribute to these tasks. Helms et al. (2013a) found, that in artificial burrowing setups, multiple individuals of $C$. hartii initially shared burrows as a mean to get underground, but, nonetheless, burrowing activity was not shared equally.

Overall, no differences were observed between males and females (Gherardi et al. 2002), and both sexes alternatively worked at the same burrow, equally participating to burrowing activity. Kouba et al. (2016) inserted P. clarkii in a situation of drought and forced to construct typical vertical burrows. In this study, it was found that burrows constructed by both male and female $P$. clarkii differed from previous studies, in that they were constructing no plugs and burrows were horizontal rather than vertical. In our study a more visible burrowing activity on the levee was observed during the day. However, it is not possible to affirm that crayfish always dig more during the day, because the activity inside the burrows was not visible, even if this is in part indirectly supported by the less frequent horizontal movements observed during the night and the observation of freshly produced tunnels after nights.

\section{Conclusion}

Our study showed the extent of burrowing behaviour of the invasive $P$. clarkii in an artificial setup and, in contrast to previous studies (e.g. Huner et al. 1984 and Huner 2002 for an overall summary), revealed how similar female and male crayfish are for burrowing activity. Considering the used experimental procedure, the observed excavation values of maximum $4 \%$ are likely an underestimation, especially because in the field a higher abundance of crayfish is present, and the number of burrows increases over time. Moreover, levees are generally not vegetated and affected by other environmental pressures (e.g. loss of stability 
and integrity due to scarce maintenance). Our results indicate how burrowing activity (considering the extent of horizontal burrows as well as crayfish reconstructing rather than reutilizing burrows) can possibly reduce the levee stability, underlining the pressure exerted by $P$. clarkii in invaded habitats. Additionally, $P$. clarkii is considered a warm water species, but its distribution in Europe and high tolerance towards low temperatures suggest its overwintering and reproduction in colder areas for which the observed burrows structures are an advantage. Possibilities to decrease the behavioural effects of $P$. clarkii on levees should be addressed in the future.

Acknowledgements We would like to thank the various students that participated in the construction of the model levees and acknowledge Lauren Tonelli for proofreading.

Open Access This article is distributed under the terms of the Creative Commons Attribution 4.0 International License (http:// creativecommons.org/licenses/by/4.0/), which permits unrestricted use, distribution, and reproduction in any medium, provided you give appropriate credit to the original author(s) and the source, provide a link to the Creative Commons license, and indicate if changes were made.

Funding Funding was provided by the Aquainvad-ED project (2020 Marie Sklodowska-Curie ITN-2014-ETN-642197).

\section{References}

Anastácio PM, Marques JC (1997) Crayfish, Procambarus clarkii, effects on initial stages of rice growth in the lower Mondego River valley (Portugal). Freshw Crayfish 11:608-617

Angeler DG, Sánchez-Carrillo S, García G, Alvarez-Cobelas M (2001) The influence of Procambarus clarkii (Cambaridae, Decapoda) on water quality and sediment characteristics in a Spanish floodplain wetland. Hydrobiologia 464:89-98

Aquiloni L, Gherardi F (2008) Mutual mate choice in crayfish: large body size is selected by both sexes, virginity by males only. J Zool 274:171-179

Aquiloni L, Brusconi S, Cecchinelli E, Tricarico E, Mazza G, Paglianti A, Gherardi F (2010) Biological control of invasive populations of crayfish: the European eel (Anguilla anguilla) as a predator of Procambarus clarkii. Biol Invasions 12:3817-3824

Aquiloni L, Buřič M, Gherardi F (2008) Crayfish females eavesdrop on fighting males before choosing the dominant mate. Curr Biol 18:R462-R463

Aquiloni L, Ilhéu M, Gherardi F (2005) Habitat use and dispersal of the invasive crayfish Procambarus clarkii in ephemeral water bodies of Portugal. MarFreshw Behav Physiol 38:225-236
Barbaresi S, Gherardi F (2000) The invasion of the alien crayfish Procambarus clarkii in Europe, with particular reference to Italy. Biol Invasions 2:259-264

Barbaresi S, Tricarico E, Gherardi F (2004) Factors inducing the intense burrowing activity of the red-swamp crayfish, Procambarus clarkii, an invasive species. Naturwissenschaften 91:342-345

Beisel JN (2001) The elusive model of a biological invasion process: time to take differences among aquatic and terrestrial ecosystems into account? Ethol Ecol Evol 13:193-195

Blackburn TM, Pyšek P, Bacher S, Carlton JT, Duncan RP, Jarošík V, Richardson D (2011) A proposed unified framework for biological invasions. Trends Ecol Evol 26:333-339

Capinha C, Brotons L, Anastácio P (2013a) Geographical variability in propagule pressure and climatic suitability explain the European distribution of two highly invasive crayfish. J Biogeogr 40:548-558

Capinha C, Larson ER, Tricarico E, Olden JD, Gherardi F (2013b) Effects of climate change, invasive species, and disease on the distribution of native European crayfishes. Conserv Biol 27:731-740

Cecchinelli E, Aquiloni L, Maltagliati G, Tricarico E, Gherardi F (2012) Use of natural pyrethrum to control the red swamp crayfish Procambarus clarkii in a rural land of Italy. Pest Manage Sci 68:839-844

Chang VC, Lange WH (1967) Laboratory and field evaluation of selected pesticides for control of the red crayfish in California rice fields. J Econ Entomol 60:473-477

Clavero M, Brotons L, Pons P, Sol D (2009) Prominent role of invasive species in avian biodiversity loss. Biol Conserv 142:2043-2049

Clavero M, García-Berthou E (2006) Homogenization dynamics and introduction routes of invasive freshwater fish in the Iberian Peninsula. Ecol Appl 16:2313-2324

Clay M, Stoeckel J, Helms B (2017) The role of abiotic and biotic cues in burrow habitat selection by juvenile crayfish. Behaviour 154:1177-1196

Condicelli M (2016) Sulle tane prodotte dal gambero Procambarus clarkii negli argini in terra: esperimenti di laboratorio 5 e 6. MSc Thesis. Scuola di Ingegneria Corso di laurea triennale in Ingegneria per l'Ambiente le Risorse ed il Territorio. University of Florence

Consumi L (2016) Studi idraulici sui rilevati arginali: verifiche di progetto degli argini delle casse di espansione da realizzarsi lungo il Torrente Mensola (Firenze) e analisi degli effetti dell'attività di scavo ad opera del gambero Procambarus clarkii. MSc Thesis. Scuola di Ingegneria Corso di laurea triennale in Ingegneria per l'Ambiente le Risorse ed il Territorio. University of Florence

Copp GH, Godard MJ, Russell IC, Peeler EJ, Gherardi F, Tricarico E, Vilizzi L (2014a) A preliminary evaluation of the European Non-native Species in Aquaculture Risk Assessment Scheme applied to species listed on Annex IV of the EU Alien Species Regulation. Fish Manag Ecol 23:1-11

Copp GH, Russell IC, Peeler EJ, Gherardi F, Tricarico E, Macleod A, Mumford J (2014b) European Non-native Species in Aquaculture Risk Analysis Scheme-a summary of assessment protocols and decision support tools for 
use of alien species in aquaculture. Fish Manag Ecol 23(1):1-11

Correia AM, Ferreira O (1995) Burrowing behavior of the introduced red swamp crayfish Procambarus clarkii (Decapoda: Cambaridae) in Portugal. J Crustacean Biol 15:248-257

Daniels WH, D'Abramo LR, Graves KF (1994) Ovarian development of female red swamp crayfish (Procambarus clarkii) as influenced by temperature and photoperiod. J Crustacean Biol 14:530-537

Darryl L (2001) Diversity and ecological significance of deepburrowing macrocrustaceans in coastal tropical waters of the Americas (Decapoda: Thalassinidea). Interciencia 26:440-449

Dorn NJ, Volin J (2009) Resistance of crayfish (Procambarus spp.) populations to wetland drying depends on species and substrate. J N Am Benthol Soc 28:766-777

Dukes JS, Mooney HA (1999) Does global change increase the success of biological invaders? Trends Ecol Evol 14:135-139

Figler MH, Blank GS, Peeke HVS (2001) Maternal territoriality as an offspring defense strategy in red swamp crayfish (Procambarus clarkii, Girard). Aggress Behav 27:391-403

Fishar DMR (2006) Red swamp crayfish (Procambarus clarkii) in River Nile, Egypt. Biodiversity Monitoring and Assessment Project (Bio Map) Nature conversion sector

Gherardi F (2000) Behaviour. In: Holdich DM (ed) Biology of freshwater crayfish. Blackwell Science, Oxford

Gherardi F (2006) Crayfish invading Europe: the case study of Procambarus clarkii. Mar Freshw Behav Physiol 39:175-191

Gherardi F, Acquistapace P (2007) Invasive crayfish in Europe: the impact of Procambarus clarkii on the littoral community of a Mediterranean lake. Freshw Biol 52:1249-1259

Gherardi F, Barbaresi S (2000) Invasive crayfish: activity patterns of Procambarus clarkii in the rice fields of the Lower Guadalquivir (Spain). Archiv für Hydrobiologie 150:153-168

Gherardi F, Barbaresi S, Salvi G (2000) Spatial and temporal patterns in the movement of Procambarus clarkii, an invasive crayfish. Aquat Sci 62:179-193

Gherardi F, Coignet A, Souty-Grosset C, Spigoli D, Aquiloni L (2013) Climate warming and the agonistic behaviour of invasive crayfishes in Europe. Freshw Biol 58:1958-1967

Gherardi F, Gollasch S, Minchin D, Olenin S, Panov V (2009) Alien invertebrates and fish in European inland waters. Handbook of alien species in Europe. Springer, Netherlands, pp 81-92

Gherardi F, Mavuti KM, Pacini NIC, Tricarico E, Harper DM (2011) The smell of danger: chemical recognition of fish predators by the invasive crayfish Procambarus clarkii. Freshw Biol 56:1567-1578

Gherardi F, Tricarico E, Ilhéu M (2002) Movement patterns of an invasive crayfish, Procambarus clarkii, in a temporary stream of southern Portugal. Ethol Ecol Evol 14:183-197

Gribsholt B, Kostka JE, Kristensen E (2003) Impact of fiddler crabs and plant roots on sediment biogeochemistry in a Georgia saltmarsh. Mar Ecol Prog Ser 259:237-251

Guan RZ (2010) Burrowing behaviour of signal crayfish, Pacifastacus leniusculus (Dana) in the River Great Ouse, Freshwater Forum, 4
Hanson GJ, Tejral RD, Hunt SL, Temple DM (2010) Internal erosion and impact of erosion resistance. In Proceedings of the 30th US Society on dams annual meeting and conference, pp. 773-784

Hasiotis ST, Mitchell CE (1993) A comparison of crayfish burrow morphologies: Triassic and Holocene fossil, paleo and neo ichnological evidence, and the identification of their burrowing signatures. Ichnos: Int J Plant Anim 2:291-314

Havel JE, Kovalenko KE, Thomaz SM, Amalfitano S, Kats LB (2015) Aquatic invasive species: challenges for the future. Hydrobiologia 740:147-170

Helms B, Budnick W, Pecora P, Skipper J, Kosnicki E, Feminella J, Stoeckel K (2013a) The influence of soil type, congeneric cues, and floodplain connectivity on the local distribution of the devil crayfish (Cambarus diogenes Girard). Freshw Sci 32:1333-1344

Helms BS, Figiel C, Rivera J, Stoeckel J, Stanton G, Keller T (2013b) Life-history observations, environmental associations, and soil preferences of the Piedmont Blue Burrower (Cambarus [Depressicambarus] harti) Hobbs. Southeast Nat 12:143-160

Henttonen P, Huner JV (1999) The introduction of alien species of crayfish in Europe: a historical introduction. Crustacean Issues 11:13-22

Hobbs RJ (1989) The nature and effects of disturbance relative to invasions. Biol Invasions: Glob Perspect 11:389-405

Hobbs HH, Hart CW (1959) The freshwater decapod crustaceans of the Apalachicola drainage system in Florida, southern Alabama, and Georgia. University of Florida

Holdich DM (1999) The negative effects of established crayfish introductions. In: Gherardi F, Holdich DM (eds) Crayfish in Europe as alien species how to make the best of a bad situation?. Brookfiled, AA Balkema, Rotterdam, pp 31-48

Holdich DM (ed) (2002) Biology of freshwater crayfish. Blackwell Science, Oxford, p 702

Holdich DM, Lowery RS (1988) Freshwater crayfish: biology, management and exploitation. Timber Press, Portland, pp 426-479

Hulme PE (2009) Trade, transport and trouble: managing invasive species pathways in an era of globalization. J Appl Ecol 46:10-18

Huner JV (1977) Introductions of Procambarus clarkii (Girard)an update. Freshw Crayfish 3:193-202

Huner JV (2002) Procambarus. In: Holdich DM (ed) Biology of freshwater crayfish. Blackwell Scientific Press, Oxford, pp 541-574

Huner JV, Barr JE, Coleman EB (1984) Red swamp crawfish: biology and exploitation. AGRIS

Huner JV, Lindqvist OV (1995) Physiological adaptations of freshwater crayfish that permit successful aquacultural enterprises. Am Zool 35:12-19

Huner JV, Meyers SP (1979) Dietary protein requirements of the red crawfish, Procambarus clarkii (Girard) (Decapoda, Cambaridae), grown in a closed system. In Proceedings of the World Mariculture Society (Vol. 10, No. 1-4, pp 751760). Oxford, UK: Blackwell Publishing Ltd

IBM Corp (2013) IBM SPSS statistics for windows, version 22.0. IBM Corp., Armonk, NY

Ilhéu M, Bernardo JM (1996) Life-history and population biology of red swamp crayfish (Procambarus clarkii) in a 
reservoir at the South of Portugal. Freshw Crayfish 11:54-59

Ilhéu M, Acquistapace P, Benvenuto C, Gherardi F (2003) Shelter use of the red-swamp crayfish (Procambarus clarkii) in dry-season stream pools. Archiv für Hydrobiol 157:535-546

Jackson RB, Banner JL, Jobbágy EG, Pockman WT, Wall DH (2002) Ecosystem carbon loss with woody plant invasion of grasslands. Nature 418:623-626

Jaspers E (1969) Environmental conditions in burrows and ponds of the Red Swamp Crawfish, Procambarus clarki (Girard), near Baton Rouge, Louisiana (Doctoral dissertation, Louisiana State University and Agricultural and Mechanical College)

Jaspers E, Avault JW Jr. (1969) Environmental conditions in burrows and ponds of the red swamp crawfish, Procambarus clarkii (Girard), near Baton Rouge, Louisiana. Proc Southeast Assoc Game Fish Comm 23:634-648

Jones CG, Lawton JH, Shachak M (1997) Positive and negative effects of organisms as physical ecosystem engineers. Ecology 78:1946-1957

Keller RP, Geist J, Jeschke J, Kühn I (2011) Invasive species in Europe: ecology, status, and policy. Environ Sci Europe 23:1

Kolar CS, Lodge DM (2001) Progress in invasion biology: predicting invaders. Trends Ecol Evol 16:199-204

Kouba A, Tíkal J, Císař P, Veselý L, Fořt M, Př́borský J, Patoka J, Buřič M (2016) The significance of droughts for hyporheic dwellers: evidence from freshwater crayfish. Sci Rep 6:26569

Lindqvist OV, Huner JV (1999) Life history characteristics of crayfish: what makes some of them good colonizers? Crustacean Issues 11:23-30

Lodge DM (1993) Biological invasions: lessons for ecology. Trends Ecol Evol 8:133-137

Lodge DM, Deines A, Gherardi F, Yeo DC, Arcella T, Baldridge AK, Howard GW (2012) Global introductions of crayfishes: evaluating the impact of species invasions on ecosystem services. Annu Rev Ecol Evol Syst 43:449-472

Lorena HAS (1978) Present situation of exotic species of crayfish introduced into Spanish continental waters. Freshw Crayfish 4:175-184

Luque GM, Bellard C, Bertelsmeier C, Bonnaud E, Genovesi P, Simberloff D, Courchamp F (2014) The 100th of the world's worst invasive alien species. Biol Invasions 16:981-985

Marques M, Banha F, Águas M, Anastácio P (2015) Environmental cues during overland dispersal by three freshwater invaders: Eriocheir sinensis, Pacifastacus leniusculus, and Procambarus clarkii (Crustacea, Decapoda). Hydrobiologia 742:81-93

Mazza G, Aquiloni L, Inghilesi AF, Giuliani C, Lazzaro L, Ferretti G, Lastrucci L, Foggi B, Tricarico E (2015) Aliens just a click away: the online aquarium trade in Italy. Manag Biol Invasions 6:253-261

Mazza G, Reboleira ASPS, Gonçalves F, Aquiloni L, Inghilesi AF, Spigoli D, Stoch F, Taiti S, Gherardi F, Tricarico E (2014a) A new threat for the groundwater ecosystems: first occurrences of the invasive crayfish Procambarus clarkii (Girard, 1852) in the European caves. J Cave Karst Stud 76:62-65
Mazza G, Tricarico E, Genovesi P, Gherardi F (2014b) Biological invaders are threats to human health: an overview. Ethol Ecol Evol 26:112-129

McGeoch MA, Butchart SH, Spear D, Marais E, Kleynhans EJ, Symes A, Hoffmann M (2010) Global indicators of biological invasion: species numbers, biodiversity impact and policy responses. Divers Distrib 16:95-108

Mendoza-Vargas L, Ortega P, Fuentes-Pardo B, Viccon-Pale JA (2016) Circadian rhythm in locomotor activity in the burrower crayfish Procambarus acanthophorus (Villalobos 1948). Biol Rhythm Res 47:93-101

Millennium Ecosystem Assessment (MEA) (2005) Ecosystems and human well-being: synthesis. Island Press, Washington, DC, p 155

Nates SF, Felder ADL (1998) Impacts of burrowing ghost shrimp, genus Lepidophthalmus Crustacea: Decapoda: Thalassinidea, on penaeid shrimp culture. J World Aquac Soc 29:188-210

Orlandini S, Moretti G, Albertson JD (2015) Evidence of an emerging levee failure mechanism causing disastrous floods in Italy. Water Resour Res 51:7995-8011

Paolo A (2014) Realizzazione di modello fisico e prove sperimentali per lo studio della vulnerabilità arginale alla filtrazione" (tesi di laurea Università degli studi di Firenze)

Pyšek P, Hulme PE, Nentwig W, Vilŕ M (2011) DAISIE project. Encycl Biol Invasions 138-142

Rahel FJ (2002) Homogenization of freshwater faunas. Annu Rev Ecol Syst 33:291-315

Ramalho RO, Anastácio PM (2015) Factors inducing overland movement of invasive crayfish (Procambarus clarkii) in a ricefield habitat. Hydrobiologia 746:135-146

Rejmánek M (1996) A theory of seed plant invasiveness: the first sketch. Biol Conserv 78:171-181

Ricciardi A (2007) Are modern biological invasions an unprecedented form of global change? Conserv Biol 21:329-336

Ricciardi A, Cohen J (2007) The invasiveness of an introduced species does not predict its impact. Biol Invasions 9:309-315

Ricciardi A, Hoopes MF, Marchetti MP, Lockwood JL (2013) Progress toward understanding the ecological impacts of non-native species. Ecol Monogr 83:263-282

Ricciardi A, Rasmussen JB (1999) Extinction rates of North American freshwater fauna. Conserv Biol 13:1220-1222

Rodríguez CF, Bécares E, Fernández-Aláez M (2003) Shift from clear to turbid phase in Lake Chozas (NW Spain) due to the introduction of American red swamp crayfish (Procambarus clarkii). Hydrobiologia 506:421-426

Rudnick DA, Halat KM, Resh VH (2000) Distribution, ecology and potential impacts of the Chinese mitten crab (Eriocheir sinensis) in San Francisco Bay. Technical Completion Reports, 206. University of California Water Resources Center: Riverside. ISBN 1-887192-12-3. 74 pp

Sala OE, Chapin FS, Armesto JJ, Berlow E, Bloomfield J, Dirzo R, Leemans R (2000) Global biodiversity scenarios for the year 2100. Science 287:1770-1774

Scalici M, Chiesa S, Scuderi S, Celauro D, Gibertini G (2010) Population structure and dynamics of Procambarus clarkii (Girard, 1852) in a Mediterranean brackish wetland (Central Italy). Biol Invasions 12:1415-1425 
Serre D, Peyras L, Tourment R, Diab Y (2008) Levee performance assessment methods integrated in a GIS to support planning maintenance actions. J Infrastruct Syst 14:201-213

Solari L, Bendoni M, Consumi L, Haubrock P, Inghilesi AF, Mazza G, Torrini M, Tricarico E (2016) Burrowing activity in channel levees: impact of the invasive swamp crayfish Procambarus clarkii. Poster presentation at the AGU Fall Meeting, San Francisco USA

Souty-Grosset C, Anastácio PM, Aquiloni L, Banha F, Choquer J, Chucholl C, Tricarico E (2016) The red swamp crayfish Procambarus clarkii in Europe: impacts on aquatic ecosystems and human well-being. Limnol-Ecol Manag Inland Waters 58:78-93

Souty-Grosset C, Carral J, Edsman L, Füreder L, Gherardi F, Grandjean F, Noël P (2006) Conservation of European crayfish, a challenge involving everybody, from the citizen to stakeholders, scientists and decision makers

Souty-Grosset C, Reynolds J, Gherardi F, Aquiloni L, Coignet A, Pinet F, Mancha-Cisneros MDM (2014) Burrowing activity of the invasive red swamp crayfish, Procambarus clarkii, in fishponds of La Brenne (France). Ethol Ecol Evol 26:263-276
Stoeckel JA, Helms BS, Cash E (2011) Evaluation of a crayfish burrowing chamber design with simulated groundwater flow. J Crustacean Biol 31:50-58

Strayer DL (2010) Alien species in fresh waters: ecological effects, interactions with other stressors, and prospects for the future. Freshw Biol 55:152-174

Tricarico E (2015) Behavior: behavioral ecology of crayfish. In: Kawai T, Faulkes Z, Scholtz G (eds) Freshwater crayfish a global overview. CRC Press, Boca Raton, pp 221-245

Tricarico E, Mazza G, Signorini F, Gherardi F (2010) Il gambero invasivo Procambarus clarkii nel Consorzio della Bonifica Parmigiana-Moglia-Secchia. Studi Trentini di Scienze Naturali (Acta Biol) 87:205-206

Van Kleunen M, Weber W, Fischer M (2010) A meta-analysis of trait differences between invasive and non-invasive plant species. Ecol Lett 13:235-245

Publisher's Note Springer Nature remains neutral with regard to jurisdictional claims in published maps and institutional affiliations. 